\title{
Biological and Spectral Studies of Newly Synthesized Triazole Schiff Bases and Their Si(IV), Sn(IV) Complexes
}

\author{
Kiran Singh, ${ }^{1}$ Parvesh Puri, ${ }^{1}$ Yogender Kumar, ${ }^{1}$ Chetan Sharma, ${ }^{2}$ and Kamal Rai Aneja ${ }^{2}$ \\ ${ }^{1}$ Department of Chemistry, Kurukshetra University Kurukshetra 136 119, India \\ ${ }^{2}$ Department of Microbiology, Kurukshetra University Kurukshetra 136 119, India
}

Correspondence should be addressed to Kiran Singh, kiransinghkuk@yahoo.co.in

Received 11 May 2011; Accepted 21 May 2011

Academic Editor: Viktor Brabec

Copyright ( $\odot 2011$ Kiran Singh et al. This is an open access article distributed under the Creative Commons Attribution License, which permits unrestricted use, distribution, and reproduction in any medium, provided the original work is properly cited.

\begin{abstract}
The Schiff bases $\mathrm{HL}^{1-3}$ have been prepared by the reaction of 5-bromothiophene-2-carboxaldehyde with 4-amino-5-mercapto-3methyl/propyl/isopropyl-s-triazole, respectively. Organosilicon(IV) and organotin(IV) complexes of formulae $\left(\mathrm{CH}_{3}\right)_{2} \mathrm{MCl}\left(\mathrm{L}^{1-3}\right)$, $\left(\mathrm{CH}_{3}\right)_{2} \mathrm{M}\left(\mathrm{L}^{1-3}\right)_{2}$ were synthesized from the reaction of $\left(\mathrm{CH}_{3}\right)_{2} \mathrm{MCl}_{2}$ and the Schiff bases in 1:1 and 1:2 molar ratio, where $\mathrm{M}=\mathrm{Si}$ and Sn. The synthesized Schiff bases and their metal complexes have been characterized with the aid of various physicochemical techniques like elemental analyses, molar conductance, UV, IR, ${ }^{1} \mathrm{H},{ }^{13} \mathrm{C},{ }^{29} \mathrm{Si}$, and ${ }^{119} \mathrm{Sn}$ NMR spectroscopy. Based on these studies, the trigonal bipyramidal and octahedral geometries have been proposed for these complexes. The ligands and their metal complexes have been screened in vitro against some bacteria and fungi.
\end{abstract}

\section{Introduction}

Recently, the research relating with metal complexes of heteronuclear Schiff bases has expanded enormously and now comprising their interesting aspects in coordination chemistry with a special emphasis in bioinorganic chemistry. A use of organosilicon and organotin compounds as reagents or intermediates in the inorganic synthesis has further strengthened their applications $[1,2]$.

More-over, metal complexes of organosilicon(IV) and organotin(IV) halides with $\mathrm{N}, \mathrm{O}$, and $\mathrm{S}$ donor ligands have received much more consideration due to their industrial, environmental, and biological applications [3-5]. The N, $\mathrm{O}$ and $\mathrm{S}$ donor ligands have been used to enhance the biological activity of organosilicon and organotin derivatives [6]. Organosilicon(IV) complexes have been subjected of interest for their versatile applications in pharmaceutical and chemical industries. Organosilicon compounds of nitrogen and sulphur containing ligands are well known for their anticarcinogenic, antibacterial, antifungal, tuberculostatic, insecticidal, and acaricidal activities [7-10]. Generally, organosilicon complexes seem to owe their antitumor properties to the immune-defensive system of the organism [11]. Similarly, organotin compounds are the active components in a number of biocidal formulations in such diverse areas as fungicides, miticides, molluscicides, antifouling paints and surface disinfectants $[12,13]$. In addition, many organotin compounds have been tested for a large variety of tumor lines and found to be more effective than traditional heavy metal anticancer drugs $[14,15]$. Ahmad et al. have also screened some organotin compounds against tumor cells [16]. Prompted by these applications, few new organosilicon and organotin compounds have already been synthesized and screened for antibacterial and antifungal activities [17, 18], and in continuation to this, in the present paper, the synthesis, characterization, and biological activities of new triazole Schiff bases and their organosilicon and organotin complexes have been carried out.

\section{Experimental}

Dried solvents were used for the synthesis of compounds. Reagents, 5-bromothiophene-2-carboxaldehyde (Spectrochem), Dimethylsilicon-dichloride (Acros) and Dimethyltindichloride (TCI-America) were used as such.

2.1. Analytical Methods and Physical Measurements. Silicon and tin were determined gravimetrically as silicondioxide 
$\left(\mathrm{SiO}_{2}\right)$ and tindioxide $\left(\mathrm{SnO}_{2}\right)$. Melting points were determined on a capillary melting point apparatus. Molar conductance measurements of $10^{-3} \mathrm{M}$ solution of metal complexes in dry DMF were measured at room temperature $\left(25 \pm 1{ }^{\circ} \mathrm{C}\right)$ with a conductivity bridge type 305 Systronic model. Carbon, hydrogen, nitrogen and sulfur were estimated using elemental analyzer Heraeus Vario EL-III Carlo Erba 1108 at CDRI Lucknow. The electronic spectra of the ligands and their metal complexes were recorded in dry methanol, on a Systronics, Double-beam spectrophotometer 2203, in the range of 600-200 nm. The IR spectra of the ligands and metal complexes were recorded in nujol mulls/KBr pellets using BUCK scientific M5000 grating spectrophotometer in the range of $4000-350 \mathrm{~cm}^{-1}$. Nuclear magnetic resonance spectra $\left({ }^{1} \mathrm{H},{ }^{13} \mathrm{C}\right)$ were recorded on BRUKER-300ACF and ${ }^{29} \mathrm{Si}$ and ${ }^{119} \mathrm{Sn}$ were recorded on BRUKER-400ACF spectrometer in $\mathrm{DMSO}_{-} \mathrm{d}_{6}$ using tetramethylsilane (TMS) as an internal standard.

2.2. Synthesis of Ligands. 4-Amino-5-mercapto-3-methyl-striazole (AMMT), 4-amino-5-mercapto-3-propyl-s-triazole (AMPT) and 4-amino-3-isoproyl-5-mercapto-s-triazole (AI MT) were synthesized by reported methods $[19,20]$. The ligands were synthesized by condensation of 5-bromothiophene-2-carboxaldehyde with AMMT, AMPT and AIMT in the medium of ethanol (Figure 1). The contents were refluxed for $4-5 \mathrm{~h}$ in absolute ethanol. After refluxing, the reaction mixture was kept overnight at room temperature and the product was filtered, washed, and recrystallized from same solvent. The elemental analyses and physical properties of the ligands are reported in Table 1. The three ligands are: $\mathrm{HL}^{1}=4$-(5-Bromothiophen-2-carboxylidene amino)-3methyl-5-mercapto-s-triazole (BTMMT), $\mathrm{HL}^{2}=4$-(5-Bromothiophen-2-carboxylidene amino)-5-mercapto-3-propyls-triazole (BTMPT), $\mathrm{HL}^{3}=4$ - (5-Bromothiophen-2-carboxylidene amino)-3-isopropyl-5-mercapto-s-triazole (BTIMT).

2.3. Synthesis of Metal Complexes. To a weighed amount of dimethylsilicondichloride $\left(\mathrm{Me}_{2} \mathrm{SiCl}_{2}\right)$ and dimethyltindichloride $\left(\mathrm{Me}_{2} \mathrm{SnCl}_{2}\right)$ in $\sim 30 \mathrm{~mL}$ of dry methanol, was added the calculated amount of the sodium salt of the ligands in $1: 1$ and 1:2 molar ratios. The sodium salts of the ligands were prepared by dissolving the appropriate amount of the sodium metal and ligands in $\sim 30 \mathrm{~mL}$ dry methanol. The reaction mixture was refluxed for about $12 \mathrm{~h}$ and then allowed to cool at room temperature and removed the chlorine as sodium chloride. The excess of solvent was removed under reduced pressure by vacuum pump and the resulting solid was repeatedly washed with 5$10 \mathrm{~mL}$ dry cyclohexane and again dried under vacuum. The elemental analyses and physical properties of the complexes are reported in Table 1.

\section{Results and Discussion}

The reactions of $\mathrm{Me}_{2} \mathrm{SiCl}_{2}$ and $\mathrm{Me}_{2} \mathrm{SnCl}_{2}$ with the sodium salt of monobasic bidentate ligands in $1: 1$ and $1: 2$ molar

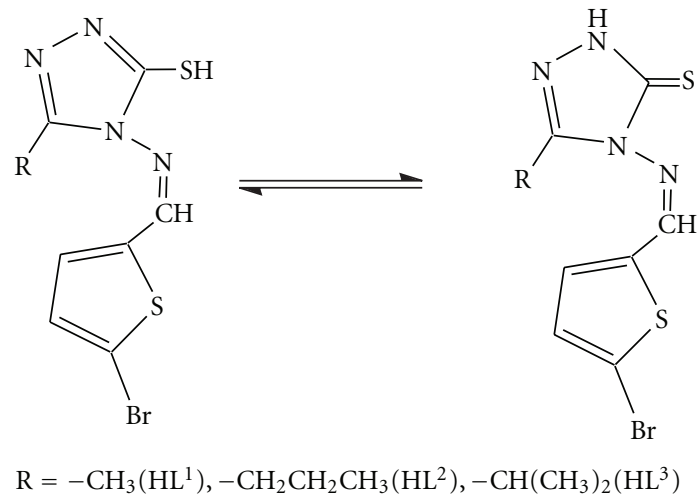

Figure 1: Structure of Schiff bases, where $\mathrm{R}=-\mathrm{CH}_{3}, \mathrm{HL}^{1}=4-(5-$ Bromothiophen-2-carboxylidene amino)-3-methyl-5-mercapto-striazole (BTMMT); $\mathrm{R}=-\mathrm{CH}_{2}-\mathrm{CH}_{2}-\mathrm{CH}_{3}, \mathrm{HL}^{2}=4-(5$-Bromothiophen-2-carboxylidene amino)-5-mercapto-3-propyl-s-triazole (BTMPT); $\mathrm{R}=-\mathrm{CH}\left(\mathrm{CH}_{3}\right)_{2}, \mathrm{HL}^{3}=4$ - (5-Bromothiophen-2-carboxylidene amino)-3-isopropyl-5-mercapto-s-triazole (BTIMT).

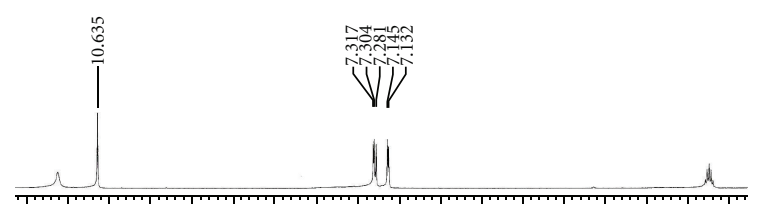

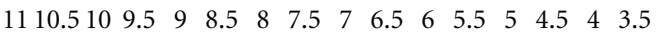
(ppm)

$H A$

慁国
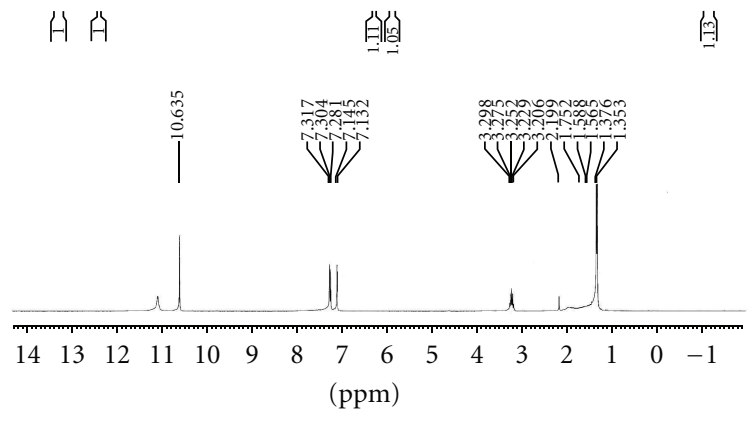

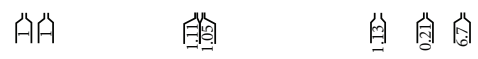

Figure 2: ${ }^{1} \mathrm{H}$ NMR spectrum of Schiff base $\left(\mathrm{HL}^{3}\right)$.

ratios in methanol medium result in the precipitation of sodium chloride $(\mathrm{NaCl})$, as shown by following reactions:

$$
\begin{aligned}
& \mathrm{Me}_{2} \mathrm{MCl}_{2}+\overparen{\mathrm{NSNa}} \stackrel{1: 1}{\longrightarrow} \mathrm{Me}_{2} \mathrm{MCl}(\overparen{\mathrm{N} \mathrm{S}})+\mathrm{NaCl} \\
& \mathrm{Me}_{2} \mathrm{MCl}_{2}+2 \mathrm{NS \textrm {Na }} \stackrel{1: 2}{\longrightarrow} \mathrm{Me}_{2} \mathrm{M}(\overparen{\mathrm{NSS}})_{2}+2 \mathrm{NaCl}
\end{aligned}
$$

where $\mathrm{M}=\mathrm{Si}$ or $\mathrm{Sn}$ and N S represent the donor sites of the ligands.

The resulting complexes have been obtained as coloured solids which are soluble in DMSO, DMF, and $\mathrm{MeOH}$. The ligands show a sharp melting point, but the complexes decompose in a range of temperature $\left(200-300^{\circ} \mathrm{C}\right)$. The molar conductivity values measured for $10^{-3} \mathrm{M}$ solutions in anhydrous DMF are in the range of $10-16 \Omega^{-1} \mathrm{~cm}^{2} \mathrm{~mol}^{-1}$, 


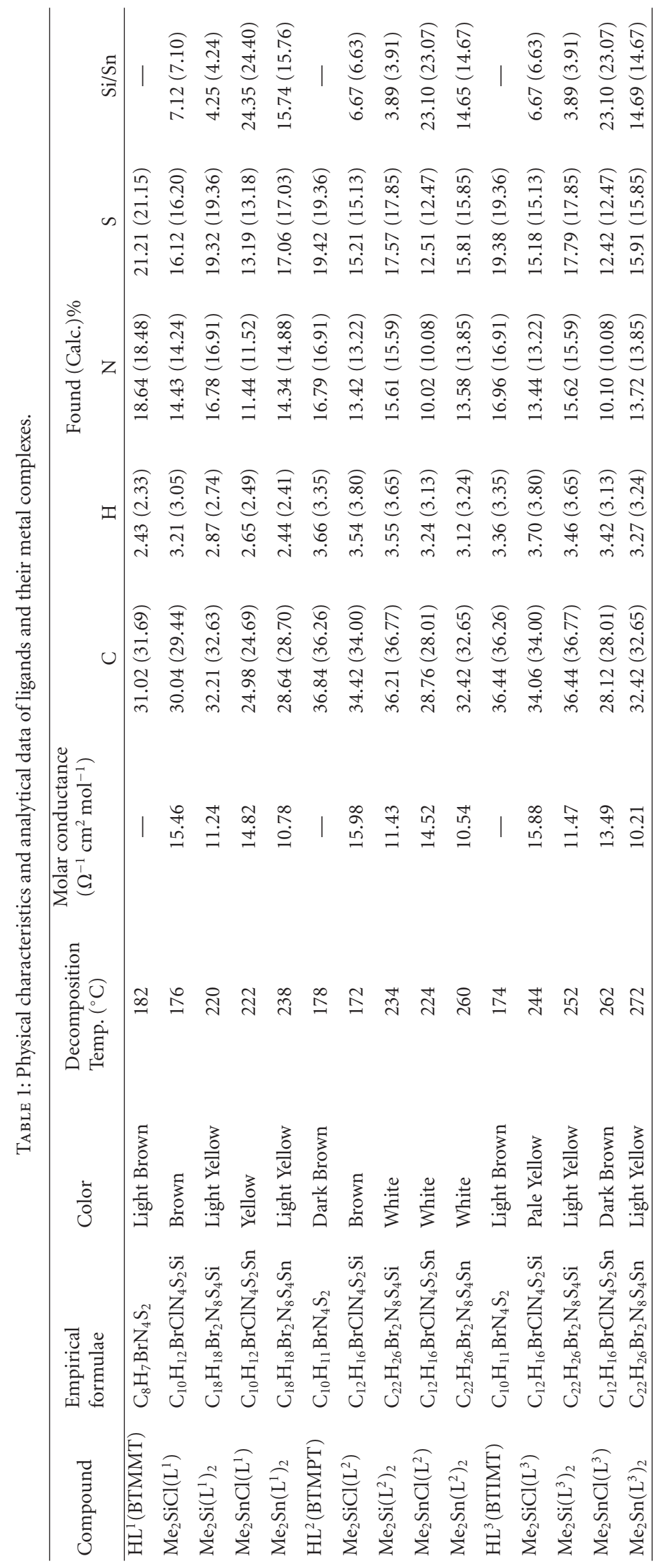


TABLE 2: IR-spectroscopic data $\left(\mathrm{cm}^{-1}\right)$ of the ligands and their metal complexes.

\begin{tabular}{|c|c|c|c|c|c|c|c|}
\hline Compound & $\nu(\mathrm{N}-\mathrm{H})$ & $\nu(-\mathrm{C}=\mathrm{N})$ & $\nu(\mathrm{C}=\mathrm{S})^{\mathrm{a}} / \nu(\mathrm{C}-\mathrm{S})^{\mathrm{b}}$ & $\nu(\mathrm{S}-\mathrm{H})$ & $\nu(\mathrm{M}-\mathrm{S})$ & $\nu(\mathrm{M}-\mathrm{N})$ & $\nu(\mathrm{M}-\mathrm{Cl})$ \\
\hline $\mathrm{HL}^{1}$ (BTMMT) & 3117 & 1597 & 1173 & 2754 & - & - & - \\
\hline $\mathrm{Me}_{2} \operatorname{SiCl}\left(\mathrm{L}^{1}\right)$ & - & 1628 & 717 & - & 453 & 572 & 418 \\
\hline $\mathrm{Me}_{2} \mathrm{Si}\left(\mathrm{L}^{1}\right)_{2}$ & - & 1628 & 710 & - & 458 & 576 & - \\
\hline $\mathrm{Me}_{2} \operatorname{SnCl}\left(\mathrm{L}^{1}\right)$ & - & 1643 & 741 & - & 403 & 528 & 378 \\
\hline $\mathrm{Me}_{2} \mathrm{Sn}\left(\mathrm{L}^{1}\right)_{2}$ & - & 1643 & 741 & - & 416 & 538 & - \\
\hline $\mathrm{HL}^{2}$ (BTMPT) & 3109 & 1589 & 1111 & 2754 & - & - & - \\
\hline $\mathrm{Me}_{2} \operatorname{SiCl}\left(\mathrm{L}^{2}\right)$ & - & 1636 & 702 & - & 452 & 570 & 420 \\
\hline $\mathrm{Me}_{2} \mathrm{Si}\left(\mathrm{L}^{2}\right)_{2}$ & - & 1697 & 741 & - & 446 & 582 & - \\
\hline $\mathrm{Me}_{2} \mathrm{SnCl}\left(\mathrm{L}^{2}\right)$ & - & 1674 & 741 & - & 416 & 542 & 396 \\
\hline $\mathrm{Me}_{2} \mathrm{Sn}\left(\mathrm{L}^{2}\right)_{2}$ & - & 1674 & 733 & - & 418 & 543 & - \\
\hline $\mathrm{HL}^{3}$ (BTIMT) & 3094 & 1582 & 1126 & 2777 & - & - & - \\
\hline $\mathrm{Me}_{2} \operatorname{SiCl}\left(\mathrm{L}^{3}\right)$ & - & 1655 & 756 & - & 456 & 563 & 426 \\
\hline $\mathrm{Me}_{2} \mathrm{Si}\left(\mathrm{L}^{3}\right)_{2}$ & - & 1659 & 741 & - & 452 & 578 & - \\
\hline $\mathrm{Me}_{2} \operatorname{SnCl}\left(\mathrm{L}^{3}\right)$ & - & 1651 & 764 & - & 410 & 536 & 395 \\
\hline $\mathrm{Me}_{2} \mathrm{Sn}\left(\mathrm{L}^{3}\right)_{2}$ & 一 & 1659 & 733 & - & 416 & 544 & - \\
\hline
\end{tabular}

$\mathrm{a}=$ Ligands.

$\mathrm{b}=$ Complexes.

TABle 3: ${ }^{1}$ HNMR chemical shifts of the ligands and their metal complexes.

\begin{tabular}{|c|c|c|c|c|}
\hline Compound & $-\mathrm{CH}=\mathrm{N}$ & $-\mathrm{SH}$ & Aromatic-H & Triazole- $\mathrm{CH}_{3},-\mathrm{CH}_{2}-\mathrm{CH}_{2}-\mathrm{CH}_{3},-\mathrm{CH}\left(\mathrm{CH}_{3}\right)$ \\
\hline $\mathrm{HL}^{1}(\mathrm{BTMMT})$ & $11.70(\mathrm{~s})$ & $10.47(\mathrm{~s})$ & $\begin{array}{l}7.30(\mathrm{~d}, 1 \mathrm{H}, J=3.6 \mathrm{~Hz}) \\
7.13(\mathrm{~d}, 1 \mathrm{H}, J=3.6 \mathrm{~Hz})\end{array}$ & $2.45(\mathrm{~s}, 3 \mathrm{H})$ \\
\hline $\mathrm{Me}_{2} \operatorname{SiCl}\left(\mathrm{L}^{1}\right)$ & $9.64(\mathrm{~s})$ & - & $\begin{array}{l}7.35(\mathrm{~d}, 1 \mathrm{H}, J=3.9 \mathrm{~Hz}) \\
7.14(\mathrm{~d}, 1 \mathrm{H}, J=3.9 \mathrm{~Hz})\end{array}$ & $2.42(\mathrm{~s}, 3 \mathrm{H})$ \\
\hline $\mathrm{Me}_{2} \mathrm{Si}\left(\mathrm{L}^{1}\right)_{2}$ & $11.12(\mathrm{~s})$ & - & $\begin{array}{l}7.42(\mathrm{~d}, 2 \mathrm{H}, J=3.9 \mathrm{~Hz}) \\
7.31(\mathrm{~d}, 2 \mathrm{H}, J=3.9 \mathrm{~Hz})\end{array}$ & $2.19(\mathrm{~s}, 6 \mathrm{H})$ \\
\hline $\mathrm{Me}_{2} \mathrm{SnCl}\left(\mathrm{L}^{1}\right)$ & $11.19(\mathrm{~s})$ & - & $\begin{array}{l}7.26(\mathrm{~d}, 1 \mathrm{H}, J=3.0 \mathrm{~Hz}) \\
7.14(\mathrm{~d}, 1 \mathrm{H}, J=3.0 \mathrm{~Hz})\end{array}$ & $2.22(\mathrm{~s}, 3 \mathrm{H})$ \\
\hline $\mathrm{Me}_{2} \mathrm{Sn}\left(\mathrm{L}^{1}\right)_{2}$ & $11.15(\mathrm{~s})$ & - & $\begin{array}{l}7.36(\mathrm{~d}, 2 \mathrm{H}, J=3.0 \mathrm{~Hz}) \\
7.29(\mathrm{~d}, 2 \mathrm{H}, J=3.0 \mathrm{~Hz})\end{array}$ & $2.10(\mathrm{~s}, 6 \mathrm{H})$ \\
\hline $\mathrm{HL}^{2}(\mathrm{BTMPT})$ & $10.91(\mathrm{~s})$ & $13.75(\mathrm{~s})$ & $\begin{array}{l}7.31(\mathrm{~d}, 1 \mathrm{H}, J=3.6 \mathrm{~Hz}) \\
7.13(\mathrm{~d}, 1 \mathrm{H}, J=3.6 \mathrm{~Hz})\end{array}$ & $\begin{array}{c}2.78(\mathrm{t}, 2 \mathrm{H}, J=7.5 \mathrm{~Hz}) ; 1.69-1.63(\mathrm{~m}, 2 \mathrm{H}) ; 1.03(\mathrm{t}, 3 \mathrm{H}, \\
J=7.5 \mathrm{~Hz})\end{array}$ \\
\hline $\mathrm{Me}_{2} \mathrm{SiCl}\left(\mathrm{L}^{2}\right)$ & $10.41(\mathrm{~s})$ & - & $\begin{array}{l}7.44(\mathrm{~d}, 1 \mathrm{H}, J=3.9 \mathrm{~Hz}) \\
7.19(\mathrm{~d}, 1 \mathrm{H}, J=3.9 \mathrm{~Hz})\end{array}$ & $\begin{array}{c}2.64(\mathrm{t}, 2 \mathrm{H}, J=7.5 \mathrm{~Hz}) ; 1.79-1.61(\mathrm{~m}, 2 \mathrm{H}) ; 0.94(\mathrm{t}, 3 \mathrm{H}, \\
J=7.5 \mathrm{~Hz})\end{array}$ \\
\hline $\mathrm{Me}_{2} \mathrm{Si}\left(\mathrm{L}^{2}\right)_{2}$ & $8.41(\mathrm{~s})$ & - & $\begin{array}{l}7.43(\mathrm{~d}, 2 \mathrm{H}, J=3.9 \mathrm{~Hz}) \\
7.21(\mathrm{~d}, 2 \mathrm{H}, J=3.9 \mathrm{~Hz})\end{array}$ & $\begin{array}{c}2.63(\mathrm{t}, 4 \mathrm{H}, J=7.5 \mathrm{~Hz}) ; 1.65-1.48(\mathrm{~m}, 4 \mathrm{H}) ; 0.96(\mathrm{t}, 6 \mathrm{H}, \\
J=7.5 \mathrm{~Hz})\end{array}$ \\
\hline $\mathrm{Me}_{2} \mathrm{SnCl}\left(\mathrm{L}^{2}\right)$ & $8.49(\mathrm{~s})$ & - & $\begin{array}{l}7.20(\mathrm{~d}, 1 \mathrm{H}, J=3.9 \mathrm{~Hz}) \\
6.88(\mathrm{~d}, 1 \mathrm{H}, J=3.9 \mathrm{~Hz})\end{array}$ & $\begin{array}{c}2.62(\mathrm{t}, 2 \mathrm{H}, J=7.5 \mathrm{~Hz}) ; 1.79-1.56(\mathrm{~m}, 2 \mathrm{H}) ; 0.94(\mathrm{t}, 3 \mathrm{H}, \\
J=7.5 \mathrm{~Hz})\end{array}$ \\
\hline $\mathrm{Me}_{2} \mathrm{Sn}\left(\mathrm{L}^{2}\right)_{2}$ & $8.87(\mathrm{~s})$ & - & $\begin{array}{l}7.36(\mathrm{~d}, 2 \mathrm{H}, J=3.6 \mathrm{~Hz}) \\
7.35(\mathrm{~d}, 2 \mathrm{H}, J=3.6 \mathrm{~Hz})\end{array}$ & $\begin{array}{c}2.68(\mathrm{t}, 4 \mathrm{H}, J=7.2 \mathrm{~Hz}) ; 1.99-1.97(\mathrm{~m}, 4 \mathrm{H}) ; 1.25(\mathrm{t}, 6 \mathrm{H}, \\
J=7.2 \mathrm{~Hz})\end{array}$ \\
\hline $\mathrm{HL}^{3}(\mathrm{BTIMT})$ & $10.63(\mathrm{~s})$ & $11.10(\mathrm{~s})$ & $\begin{array}{l}7.31(\mathrm{~d}, 1 \mathrm{H}, J=3.9 \mathrm{~Hz}) \\
7.13(\mathrm{~d}, 1 \mathrm{H}, J=3.9 \mathrm{~Hz})\end{array}$ & $3.29-3.20(\mathrm{~m}, 1 \mathrm{H}) ; 1.36(\mathrm{~d}, 6 \mathrm{H}, J=6.9 \mathrm{~Hz})$ \\
\hline $\mathrm{Me}_{2} \operatorname{SiCl}\left(\mathrm{L}^{3}\right)$ & $10.32(\mathrm{~s})$ & - & $\begin{array}{l}7.51(\mathrm{~d}, 1 \mathrm{H}, J=3.6 \mathrm{~Hz}) \\
7.23(\mathrm{~d}, 1 \mathrm{H}, J=3.6 \mathrm{~Hz})\end{array}$ & $3.28-3.12(\mathrm{~m}, 1 \mathrm{H},) ; 1.25(\mathrm{~d}, 6 \mathrm{H}, J=7.2 \mathrm{~Hz})$ \\
\hline $\mathrm{Me}_{2} \mathrm{Si}\left(\mathrm{L}^{3}\right)_{2}$ & $8.44(\mathrm{~s})$ & - & $\begin{array}{l}7.10(\mathrm{~d}, 2 \mathrm{H}, J=3.9 \mathrm{~Hz}) \\
7.02(\mathrm{~d}, 2 \mathrm{H}, J=3.9 \mathrm{~Hz})\end{array}$ & $3.14-2.86(\mathrm{~m}, 2 \mathrm{H}) ; 1.25(\mathrm{~d}, 12 \mathrm{H}, J=7.2 \mathrm{~Hz})$ \\
\hline $\mathrm{Me}_{2} \mathrm{SnCl}\left(\mathrm{L}^{3}\right)$ & $8.40(\mathrm{~s})$ & - & $\begin{array}{l}7.12(\mathrm{~d}, 1 \mathrm{H}, J=3.9 \mathrm{~Hz}) \\
7.08(\mathrm{~d}, 1 \mathrm{H}, J=3.9 \mathrm{~Hz})\end{array}$ & $2.87-2.73(\mathrm{~m}, 1 \mathrm{H}) ; 1.17(\mathrm{~d}, 6 \mathrm{H}, J=7.2 \mathrm{~Hz})$ \\
\hline $\mathrm{Me}_{2} \mathrm{Sn}\left(\mathrm{L}^{3}\right)_{2}$ & $8.48(s)$ & - & $\begin{array}{l}7.10(\mathrm{~d}, 2 \mathrm{H}, J=3.9 \mathrm{~Hz}) \\
7.09(\mathrm{~d}, 2 \mathrm{H}, J=3.9 \mathrm{~Hz})\end{array}$ & $2.92-2.83(\mathrm{~m}, 2 \mathrm{H}) ; 1.18(\mathrm{~d}, 12 \mathrm{H}, J=7.2 \mathrm{~Hz})$ \\
\hline
\end{tabular}


TABLE 4: $\mathrm{C}^{13}$ NMR chemical shifts of the ligands and their metal complexes.

\begin{tabular}{|c|c|c|c|c|c|c|c|c|c|c|c|}
\hline Compound & $\mathrm{C}_{1}$ & $\mathrm{C}_{2}$ & $\mathrm{C}_{3}$ & $\mathrm{C}_{4}$ & $\mathrm{C}_{5}$ & $\mathrm{C}_{6}$ & $\mathrm{C}_{7}$ & $\mathrm{C}_{8}$ & $\mathrm{C}_{9}$ & $\mathrm{C}_{10}$ & $\mathrm{M}-\mathrm{CH}_{3}$ \\
\hline $\mathrm{HL}^{1}(\mathrm{BTMMT})$ & 124.05 & 135.85 & 139.06 & 143.92 & 166.42 & 153.51 & 157.32 & 15.67 & - & - & - \\
\hline $\operatorname{Me}_{2} \operatorname{SiCl}\left(\mathrm{L}^{1}\right)$ & 131.77 & 132.39 & 137.24 & 137.94 & 183.07 & 138.32 & 156.08 & 9.5 & - & - & 18.11 \\
\hline $\mathrm{Me}_{2} \mathrm{Si}\left(\mathrm{L}^{1}\right)_{2}$ & 116.70 & 132.06 & 133.60 & 141.23 & 160.96 & 147.79 & 149.04 & 11.32 & - & - & 28.22 \\
\hline $\mathrm{Me}_{2} \mathrm{SnCl}\left(\mathrm{L}^{1}\right)$ & 120.65 & 132.03 & 132.98 & 142.52 & 162.54 & 147.89 & 148.26 & 11.65 & - & - & 30.11 \\
\hline $\mathrm{Me}_{2} \mathrm{Sn}\left(\mathrm{L}^{1}\right)_{2}$ & 116.03 & 131.94 & 132.82 & 141.82 & 161.23 & 147.33 & 147.58 & 11.37 & - & - & 32.11 \\
\hline $\mathrm{HL}^{2}(\mathrm{BTMPT})$ & 120.15 & 131.09 & 134.59 & 138.97 & 162.23 & 152.73 & 152.92 & 13.69 & 19.29 & 26.91 & - \\
\hline $\mathrm{Me}_{2} \operatorname{SiCl}\left(\mathrm{L}^{2}\right)$ & 119.30 & 131.84 & 135.64 & 139.04 & 183.06 & 154.32 & 156.02 & 13.76 & 19.44 & 26.81 & 18.23 \\
\hline $\mathrm{Me}_{2} \mathrm{Si}\left(\mathrm{L}^{2}\right)_{2}$ & 128.18 & 129.28 & 131.98 & 141.72 & 161.81 & 153.26 & 154.25 & 14.58 & 19.02 & 25.95 & 24.66 \\
\hline $\mathrm{Me}_{2} \operatorname{SnCl}\left(\mathrm{L}^{2}\right)$ & 126.23 & 128.56 & 131.23 & 140.58 & 162.48 & 152.56 & 154.85 & 14.23 & 18.65 & 26.42 & 31.32 \\
\hline $\mathrm{Me}_{2} \mathrm{Sn}\left(\mathrm{L}^{2}\right)_{2}$ & 124.26 & 130.45 & 132.05 & 141.62 & 161.98 & 153.26 & 154.26 & 14.42 & 18.87 & 26.86 & 32.00 \\
\hline $\mathrm{HL}^{3}$ (BTIMT) & 124.18 & 135.96 & 139.22 & 143.95 & 160.79 & 157.86 & 157.26 & 30.27 & 24.44 & 24.44 & - \\
\hline $\mathrm{Me}_{2} \operatorname{SiCl}\left(\mathrm{L}^{3}\right)$ & 118.67 & 132.03 & 135.82 & 139.08 & 161.95 & 154.71 & 154.98 & 25.56 & 19.79 & 19.79 & 19.12 \\
\hline $\mathrm{Me}_{2} \mathrm{Si}\left(\mathrm{L}^{3}\right)_{2}$ & 120.42 & 129.45 & 133.25 & 138.55 & 160.78 & 152.53 & 151.25 & 28.45 & 20.25 & 22.76 & 29.10 \\
\hline $\mathrm{Me}_{2} \operatorname{SnCl}\left(\mathrm{L}^{3}\right)$ & 122.62 & 128.46 & 132.46 & 139.42 & 161.86 & 153.24 & 154.25 & 27.56 & 19.45 & 24.57 & 29.88 \\
\hline $\mathrm{Me}_{2} \mathrm{Sn}\left(\mathrm{L}^{3}\right)_{2}$ & 124.56 & 130.54 & 135.03 & 141.21 & 162.46 & 154.48 & 153.24 & 28.89 & 21.22 & 26.43 & 31.89 \\
\hline
\end{tabular}

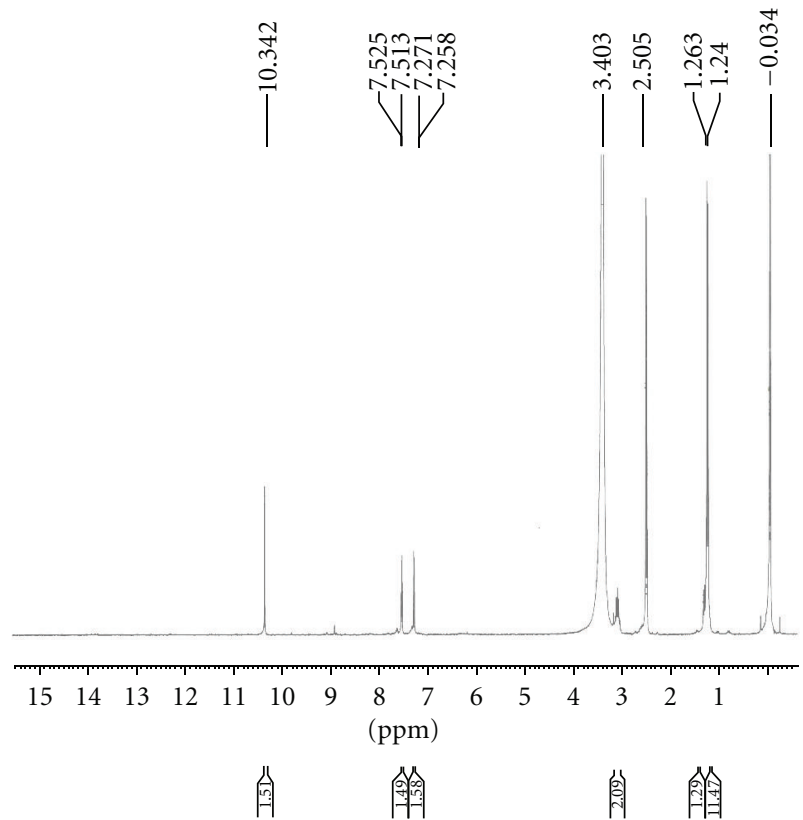

Figure $3:{ }^{1} \mathrm{H}$ NMR spectrum of $\mathrm{Si}(1: 1)$ metal complex of ligand $\left(\mathrm{HL}^{3}\right)$.

showing that all $1: 1$ and $1: 2$ complexes are nonelectrolytic in nature Table 1.

3.1. Electronic Spectra. The electronic spectra of the ligands $\mathrm{HL}^{1-3}$ and their corresponding $\mathrm{Si}(\mathrm{IV})$ and $\mathrm{Sn}(\mathrm{IV})$ metal complexes were recorded. The electronic spectra of ligands $\mathrm{HL}^{1}, \mathrm{HL}^{2}$, and $\mathrm{HL}^{3}$ exhibit maxima at $388 \mathrm{~nm}, 364 \mathrm{~nm}$, and $387 \mathrm{~nm}$, respectively, which could be assigned to the $n-\pi^{*}$ transition of the azomethine group. These bands show a blue shift in $1: 1$ and $1: 2, \mathrm{Si}(\mathrm{IV})$ and $\mathrm{Sn}(\mathrm{IV})$ metal complexes and appear at $368 \mathrm{~nm}, 369 \mathrm{~nm}, 358 \mathrm{~nm}, 369 \mathrm{~nm}, 362 \mathrm{~nm}$, $364 \mathrm{~nm}, 359 \mathrm{~nm}, 362 \mathrm{~nm}, 372 \mathrm{~nm}, 368 \mathrm{~nm}, 376 \mathrm{~nm}$ and

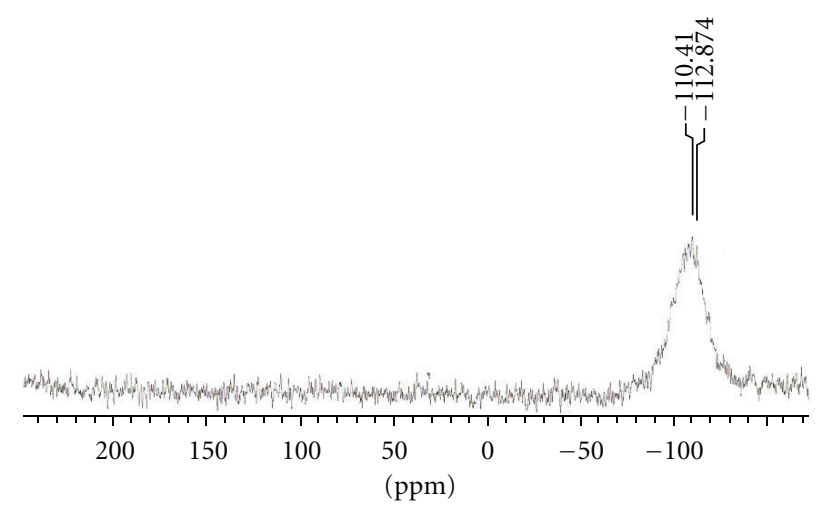

Figure $4:{ }^{29} \mathrm{Si}$ NMR spectrum of $\mathrm{Si}(1: 1)$ metal complex of ligand $\left(\mathrm{HL}^{1}\right)$.

$366 \mathrm{~nm}$ for $\mathrm{Me}_{2} \mathrm{SiCl}\left(\mathrm{L}^{1}\right), \mathrm{Me}_{2} \mathrm{Si}\left(\mathrm{L}^{1}\right)_{2}, \mathrm{Me}_{2} \mathrm{SnCl}\left(\mathrm{L}^{1}\right), \mathrm{Me}_{2} \mathrm{Sn}$ $\left(\mathrm{L}^{1}\right)_{2}, \mathrm{Me}_{2} \mathrm{SiCl}\left(\mathrm{L}^{2}\right), \mathrm{Me}_{2} \mathrm{Si}\left(\mathrm{L}^{2}\right)_{2}, \mathrm{Me}_{2} \mathrm{SnCl}\left(\mathrm{L}^{2}\right), \mathrm{Me}_{2} \mathrm{Sn}\left(\mathrm{L}^{2}\right)_{2}$, $\mathrm{Me}_{2} \mathrm{SiCl}\left(\mathrm{L}^{3}\right), \mathrm{Me}_{2} \mathrm{Si}\left(\mathrm{L}^{3}\right)_{2}, \mathrm{Me}_{2} \mathrm{SnCl}\left(\mathrm{L}^{3}\right)$, and $\mathrm{Me}_{2} \mathrm{Sn}\left(\mathrm{L}^{3}\right)_{2}$, respectively, and indicating the coordination of azomethine nitrogen atom to the metal atom [16]. In addition to this, the three medium intensity bands at $244 \mathrm{~nm}, 240 \mathrm{~nm}$, and $260 \mathrm{~nm}$ due to $\pi-\pi^{*}$ transition in the ligands remain unchanged or show a minor change in the spectra of metal complexes [17].

3.2. IR Spectra. In the IR spectra of the ligands, a broad band in the region of $3117-3094 \mathrm{~cm}^{-1}$ due to $v(\mathrm{~N}-\mathrm{H})$ [13] and a band at $\sim 1120 \mathrm{~cm}^{-1}$ due to $\nu(\mathrm{C}=\mathrm{S})$ [21], indicating the thione form, while a weak band observed around $2750 \mathrm{~cm}^{-1}$ due to $\nu(\mathrm{S}-\mathrm{H})$ vibrations suggested that the Schiff bases exhibit thiol-thione tautomerism (Figure 1) $[22,23]$. The deprotonation of $-\mathrm{SH}$ group of triazole was indicated by the absence of bands in the spectra of metal complexes due to $v(\mathrm{~S}-\mathrm{H}), v(\mathrm{C}=\mathrm{S})$, and $\nu(\mathrm{N}-\mathrm{H})$. A new band appears $\sim 740 \mathrm{~cm}^{-1}$ in the spectra of the complexes, which 


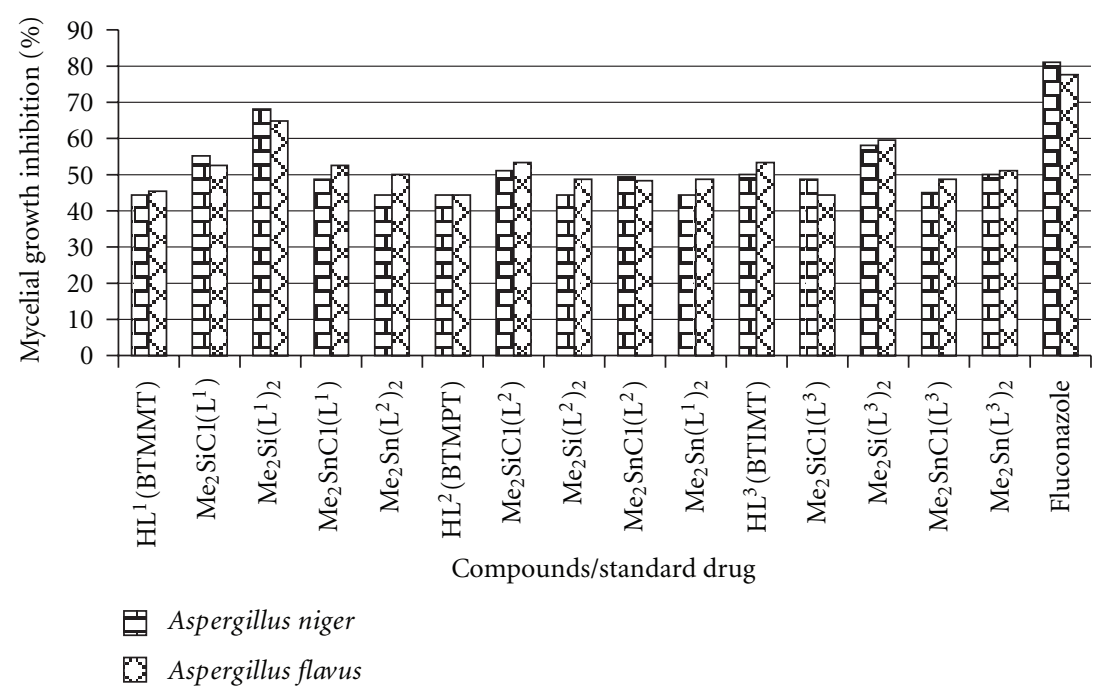

FIGURE 5: Comparison of antifungal activity of compounds with commercial antibiotic.

is assigned to $\nu(\mathrm{C}-\mathrm{S})$ and which indicates the complexation of ligands through S-atom with the metal atom. The metal sulphur bond formation is further supported by a band at $\sim 452 \mathrm{~cm}^{-1}$ and $\sim 426 \mathrm{~cm}^{-1}$ for $\nu(\mathrm{Si}-\mathrm{S})$ [24] and $\nu(\mathrm{Sn}-$ S) [25] in the spectra of organosilicon and organotin complexes, respectively. A sharp and strong band in the region of $1582-1597 \mathrm{~cm}^{-1}$ for $v(\mathrm{~N}=\mathrm{CH})$ [26] in case of ligands, was shifted to a higher wavelength number and appears in the region of $1628-1674 \mathrm{~cm}^{-1}$ in the spectra of metal complexes, indicating the coordination of ligands through azomethine nitrogen to the metal atom. The metal nitrogen bond was further supported by the presence of a band at about $\sim 535 \mathrm{~cm}^{-1}$ for $\nu(\mathrm{Sn}-\mathrm{N})$ [27] and $\sim 575 \mathrm{~cm}^{-1}$ for $\nu(\mathrm{Si}-\mathrm{N})$ [28]. A strong band in the region of $425-$ $378 \mathrm{~cm}^{-1}$ was assigned to $v(\mathrm{M}-\mathrm{Cl})$ [29]. The IR-spectral data of the ligands and their metal complexes are listed in Table 2.

3.3. ${ }^{1} \mathrm{H}$ NMR Spectra. The ${ }^{1} \mathrm{H}$ NMR spectra of the ligands show the $-\mathrm{SH}$ proton signal at $\delta 10.47(\mathrm{~s}), \delta 13.75(\mathrm{~s})$, and $\delta 11.10$ (s) ppm for $\mathrm{HL}^{1}, \mathrm{HL}^{2}$, and $\mathrm{HL}^{3}$, respectively [26] (Figure 2). The disappearance of the signal due to - $\mathrm{SH}$ proton in the spectra of metal complexes indicates the deprotonation of the thiol group and supports the coordination of ligand through sulphur atom to the metal atom. A signal at $\delta 11.72(\mathrm{~s}), 10.91(\mathrm{~s})$, and 10.63 (s) ppm was observed due to azomethine proton in the spectra of free ligands $\mathrm{HL}^{1}, \mathrm{HL}^{2}$ and $\mathrm{HL}^{3}$, respectively, which moves upfield in the ${ }^{1} \mathrm{H}$ NMR spectra of metal complexes [13], indicates the bonding through the azomethine nitrogen atom to the central metal atom (Figure 3 ). The aromatic protons of the thiophene moiety in the ligands appear as two doublets, which remain more or less unchanged in the ${ }^{1} \mathrm{H}$ NMR spectra of the metal complexes. Some additional signals at $\delta 2.45 \mathrm{ppm}\left(\mathrm{s}, \mathrm{CH}_{3}\right.$, Triazole), $\delta 2.78 \mathrm{ppm}\left(\mathrm{t}, \mathrm{CH}_{2}-\right.$ $\mathrm{CH}_{2}-\mathrm{CH}_{3}$, Triazole), $\delta$ 1.69-1.63 ppm (m, $\mathrm{CH}_{2}-\mathrm{CH}_{2}-\mathrm{CH}_{3}$, Triazole), $\delta 1.03 \mathrm{ppm}\left(\mathrm{t}, \mathrm{CH}_{2}-\mathrm{CH}_{2}-\mathrm{CH}_{3}\right.$, Triazole), $\delta 3.29-$ $3.20 \mathrm{ppm}\left(\mathrm{CH}\left(\mathrm{CH}_{3}\right)_{2}\right.$, Triazole $), \delta 1.36 \mathrm{ppm}\left(\mathrm{d}, \mathrm{CH}\left(\mathrm{CH}_{3}\right)_{2}\right.$, Triazole) and also appeared in the ${ }^{1}$ HNMR spectra of the ligands, and their metal complexes, reported in the Table 3. The additional signals in the region $\delta 0.3-1.5 \mathrm{ppm}$ are also observed in the spectra of complexes due to $\mathrm{CH}_{3}-\mathrm{M}$ group.

3.4. ${ }^{13} \mathrm{C} N M R$ Spectra. The ${ }^{13} \mathrm{C}$ NMR spectral data of ligands $\mathrm{HL}^{1}, \mathrm{HL}^{2}$, and $\mathrm{HL}^{3}$, and their corresponding $1: 1$ and 1:2 metal complexes [17, 18] have been reported in Table 4. The signal due to the carbon atom attached to the azomethine group in the ligands $\mathrm{HL}^{1}, \mathrm{HL}^{2}$, and $\mathrm{HL}^{3}$ appear at $\delta 166.42 \mathrm{ppm}, \delta 162.23 \mathrm{ppm}$, and $\delta 160.79 \mathrm{ppm}$, respectively. However, in the spectra of the corresponding metal complexes, the shift in the ${ }^{13} \mathrm{C}$ resonance indicate the coordination of nitrogen atom of azomethine group with the central atom in $1: 1$ and $1: 2$ metal complexes. Moreover, the shifting of the ${ }^{13} \mathrm{C}$ resonance of triazole which is attached to sulphur atom in the spectra of $1: 1$ and $1: 2$ metal complexes compared to the free ligands indicates the coordination through sulphur atom with the central metal atom. The new signal due to the methyl groups attached to the metal atom in the spectra of metal complexes has also been reported in Table 4.

3.5. ${ }^{29} \mathrm{Si}$ and ${ }^{119} \mathrm{Sn}$ NMR Spectra. The value of $\delta{ }^{29} \mathrm{Si}$ and $\delta{ }^{119} \mathrm{Sn}$ indicates the coordination number of the central metal atom in the corresponding complexes [30], and generally (Figure 4), ${ }^{29} \mathrm{Si}$ and ${ }^{119} \mathrm{Sn}$ chemical shifts move to lower frequency with increasing coordination number of the metal atoms. The spectrum shows in each case only a sharp singlet indicating the formation of single species. ${ }^{29} \mathrm{Si}$ and ${ }^{119} \mathrm{Sn}$ NMR spectra of $\left\{\mathrm{Me}_{2} \mathrm{SiCl}\left(\mathrm{L}^{1}\right)\right\},\left\{\mathrm{Me}_{2} \mathrm{Si}\left(\mathrm{L}^{1}\right)_{2}\right\},\left\{\mathrm{Me}_{2} \mathrm{SnCl}\left(\mathrm{L}^{1}\right)\right\}$, and $\left\{\mathrm{Me}_{2} \mathrm{Sn}\right.$ $\left.\left(\mathrm{L}^{1}\right)_{2}\right\}$ complexes show sharp signals at $\delta-110.41 \mathrm{ppm}$, $\delta-123.35 \mathrm{ppm}, \delta-176.46 \mathrm{ppm}$, and $\delta-265.26 \mathrm{ppm}$, respectively, Which is indicative of pentacoordinated and hexacoordinated around the silicon and tin atom [8]. 
TABLE 5: In vitro antibacterial activity of the ligands and their metal complexes.

\begin{tabular}{lcccc}
\hline \multirow{2}{*}{ Compounds } & \multicolumn{5}{c}{ Zone of inhibition $(\mathrm{mm})^{\mathrm{a}}$} \\
& S. aureus & B. subtilis & E. coli & P. aeruginosa \\
\hline $\mathrm{HL}^{1}(\mathrm{BTMMT})$ & 16.2 & 15.6 & - & - \\
$\mathrm{Me}_{2} \mathrm{SiCl}\left(\mathrm{L}^{1}\right)$ & 21.6 & - & - & - \\
$\mathrm{Me}_{2} \mathrm{Si}\left(\mathrm{L}^{1}\right)_{2}$ & 20.3 & - & - & - \\
$\mathrm{Me}_{2} \mathrm{SnCl}\left(\mathrm{L}^{1}\right)$ & 24.6 & 22.6 & - & - \\
$\mathrm{Me}_{2} \mathrm{Sn}\left(\mathrm{L}^{1}\right)_{2}$ & - & 18.6 & - & - \\
$\mathrm{HL}^{2}(\mathrm{BTMPT})$ & 18.8 & 18.6 & - & - \\
$\mathrm{Me}_{2} \mathrm{SiCl}\left(\mathrm{L}^{2}\right)$ & 23.6 & 21.3 & - & - \\
$\mathrm{Me}_{2} \mathrm{Si}\left(\mathrm{L}^{2}\right)_{2}$ & 17.3 & 15.2 & - & - \\
$\mathrm{Me}_{2} \mathrm{SnCl}\left(\mathrm{L}^{2}\right)$ & - & - & - & - \\
$\mathrm{Me}_{2} \mathrm{Sn}\left(\mathrm{L}^{2}\right)_{2}$ & 15.3 & 16.3 & - & - \\
$\mathrm{HL}^{3}(\mathrm{BTIMT})$ & - & 15.9 & - & - \\
$\mathrm{Me}_{2} \mathrm{SiCl}\left(\mathrm{L}^{3}\right)$ & - & 20.2 & - & - \\
$\mathrm{Me}_{2} \mathrm{Si}\left(\mathrm{L}^{3}\right)_{2}$ & - & 16.2 & - & - \\
$\mathrm{Me}_{2} \mathrm{SnCl}\left(\mathrm{L}^{3}\right)$ & - & 16.8 & - & - \\
$\mathrm{Me}_{2} \mathrm{Sn}\left(\mathrm{L}^{3}\right)_{2}$ & - & 15.3 & - & - \\
$\mathrm{Ciprofloxacin}$ & 27.6 & 26 & - & - \\
\hline
\end{tabular}

-: No activity.

${ }^{\mathrm{a}}$ Values, including diameter of the well $(8 \mathrm{~mm})$, are means of three replicates.

TABLE 6: Minimum inhibitory concentration (MIC) in $\mu \mathrm{g} / \mathrm{mL}$ of the ligands and their metal complexes.

\begin{tabular}{lcc}
\hline Compound & S. aureus & B. subtilis \\
\hline $\mathrm{HL}^{1}(\mathrm{BTMMT})$ & $>128$ & 128 \\
$\mathrm{Me}_{2} \mathrm{SiCl}\left(\mathrm{L}^{1}\right)$ & 64 & $\mathrm{Nt}$ \\
$\mathrm{Me}_{2} \mathrm{Si}\left(\mathrm{L}^{1}\right)_{2}$ & 64 & $\mathrm{Nt}$ \\
$\mathrm{Me}_{2} \mathrm{SnCl}\left(\mathrm{L}^{1}\right)$ & 28 & 54 \\
$\mathrm{Me}_{2} \mathrm{Sn}\left(\mathrm{L}^{1}\right)_{2}$ & $\mathrm{Nt}$ & 64 \\
$\mathrm{HL}^{2}(\mathrm{BTMPT})$ & $\mathrm{Nt}$ & 128 \\
$\mathrm{Me}_{2} \mathrm{SiCl}\left(\mathrm{L}^{2}\right)$ & 28 & 58 \\
$\mathrm{Me}_{2} \mathrm{Si}\left(\mathrm{L}^{2}\right)_{2}$ & 128 & $>128$ \\
$\mathrm{Me}_{2} \mathrm{SnCl}\left(\mathrm{L}^{2}\right)$ & - & - \\
$\mathrm{Me}_{2} \mathrm{Sn}\left(\mathrm{L}^{2}\right)_{2}$ & 128 & 128 \\
$\mathrm{HL}^{3}(\mathrm{BTIMT})$ & $\mathrm{Nt}$ & 128 \\
$\mathrm{Me}_{2} \mathrm{SiCl}\left(\mathrm{L}^{3}\right)$ & $\mathrm{Nt}$ & 128 \\
$\mathrm{Me}_{2} \mathrm{Si}\left(\mathrm{L}^{3}\right)_{2}$ & $\mathrm{Nt}$ & 128 \\
$\mathrm{Me}_{2} \mathrm{SnCl}\left(\mathrm{L}^{3}\right)$ & $\mathrm{Nt}$ & 128 \\
$\mathrm{Me}_{2} \mathrm{Sn}\left(\mathrm{L}^{3}\right)_{2}$ & $\mathrm{Nt}$ & 128 \\
$\mathrm{Ciprofloxacin}$ & 5 & 5 \\
\hline
\end{tabular}

Nt: Not tested.

\section{Biological Activities}

The bactericidal and fungicidal activities of the free ligands and their metal complexes against various gram positive and gram negative bacteria and fungi are reported in Tables 5, 6, and 7.
TABLE 7: In vitro antifungal activity of the ligands and their metal complexes.

\begin{tabular}{lcc}
\hline \multirow{2}{*}{ Compound } & \multicolumn{2}{c}{ Mycelial growth inhibition (\%) } \\
& Aspergillus niger & Aspergillus flavus \\
\hline $\mathrm{HL}^{1}(\mathrm{BTMMT})$ & 44.4 & 45.5 \\
$\mathrm{Me}_{2} \mathrm{SiCl}\left(\mathrm{L}^{1}\right)$ & 55.2 & 52.5 \\
$\mathrm{Me}_{2} \mathrm{Si}\left(\mathrm{L}^{1}\right)_{2}$ & $\mathbf{6 8 . 2}$ & $\mathbf{6 4 . 8}$ \\
$\mathrm{Me}_{2} \mathrm{SnCl}\left(\mathrm{L}^{1}\right)$ & 48.8 & 52.5 \\
$\mathrm{Me}_{2} \mathrm{Sn}\left(\mathrm{L}^{1}\right)_{2}$ & 44.4 & 50 \\
$\mathrm{HL}^{2}(\mathrm{BTMPT})$ & 44.4 & 44.4 \\
$\mathrm{Me}_{2} \mathrm{SiCl}\left(\mathrm{L}^{2}\right)$ & 51.1 & 53.3 \\
$\mathrm{Me}_{2} \mathrm{Si}\left(\mathrm{L}^{2}\right)_{2}$ & 44.4 & 48.8 \\
$\mathrm{Me}_{2} \mathrm{SnCl}\left(\mathrm{L}^{2}\right)$ & 49.4 & 48.4 \\
$\mathrm{Me}_{2} \mathrm{Sn}\left(\mathrm{L}^{2}\right)_{2}$ & 44.4 & 48.8 \\
$\mathrm{HL}^{3}(\mathrm{BTIMT})$ & 50 & 53.3 \\
$\mathrm{Me}_{2} \mathrm{SiCl}\left(\mathrm{L}^{3}\right)$ & 48.8 & 44.4 \\
$\mathrm{Me}_{2} \mathrm{Si}\left(\mathrm{L}^{3}\right)_{2}$ & 58.1 & 59.5 \\
$\mathrm{Me}_{2} \mathrm{SnCl}\left(\mathrm{L}^{3}\right)$ & 45 & 48.8 \\
$\mathrm{Me}_{2} \mathrm{Sn}\left(\mathrm{L}^{3}\right)_{2}$ & 50 & 51.1 \\
$\mathrm{Fluconazole}$ & 81.1 & 77.7 \\
\hline
\end{tabular}

4.1. In Vitro Antibacterial Assay. The newly synthesized ligands and their metal complexes were screened for their antibacterial activities against test bacteria namely Staphylococcus aureus, Bacillus subtilis (Gram positive), Escherichia coli, and Pseudomonas aeruginosa (Gram negative). The activity is determined by reported Agar well diffusion method [31,32]. All the microbial cultures were adjusted to $0.5 \mathrm{McF}$ arland standards, which is visually comparable to a microbial suspension of approximately $1.5 \times 10^{8} \mathrm{cfu} / \mathrm{mL}$. $20 \mathrm{~mL}$ of Mueller Hinton Agar medium was poured into each petri plate and plates were swabbed with $100 \mu \mathrm{L}$ inocula of the test microorganisms and kept for 15 min for adsorption. Using sterile cork borer of $8 \mathrm{~mm}$ diameter, wells were bored into the seeded agar plates, and these were loaded with a $100 \mu \mathrm{L}$ volume with concentration of $4.0 \mathrm{mg} / \mathrm{mL}$ of each compound reconstituted in the DMSO. All the plates were incubated at $37^{\circ} \mathrm{C}$ for $24 \mathrm{hrs}$. Antibacterial activity of each synthetic compound was evaluated by measuring the zone of growth inhibition against the test organisms with zone reader (Hi Antibiotic zone scale). DMSO was used as a negative control, whereas Ciprofloxacin was used as positive control. This procedure was performed in three replicate plates for each organism.

4.2. Determination of Minimum Inhibitory Concentration (MIC). MIC of the various compounds against bacterial strains was tested through a macrodilution tube method as recommended by NCCLS [33]. In this method, the various test concentrations of synthesized compounds were made from 128 to $0.25 \mu \mathrm{g} / \mathrm{mL}$ in sterile tubes nos. 1 to $10.100 \mu \mathrm{L}$ sterile Mueller Hinton Broth (MHB) was poured in each sterile tube followed by addition of $200 \mu \mathrm{L}$ test compound in tube 1. Twofold serial dilutions were carried out from tube 


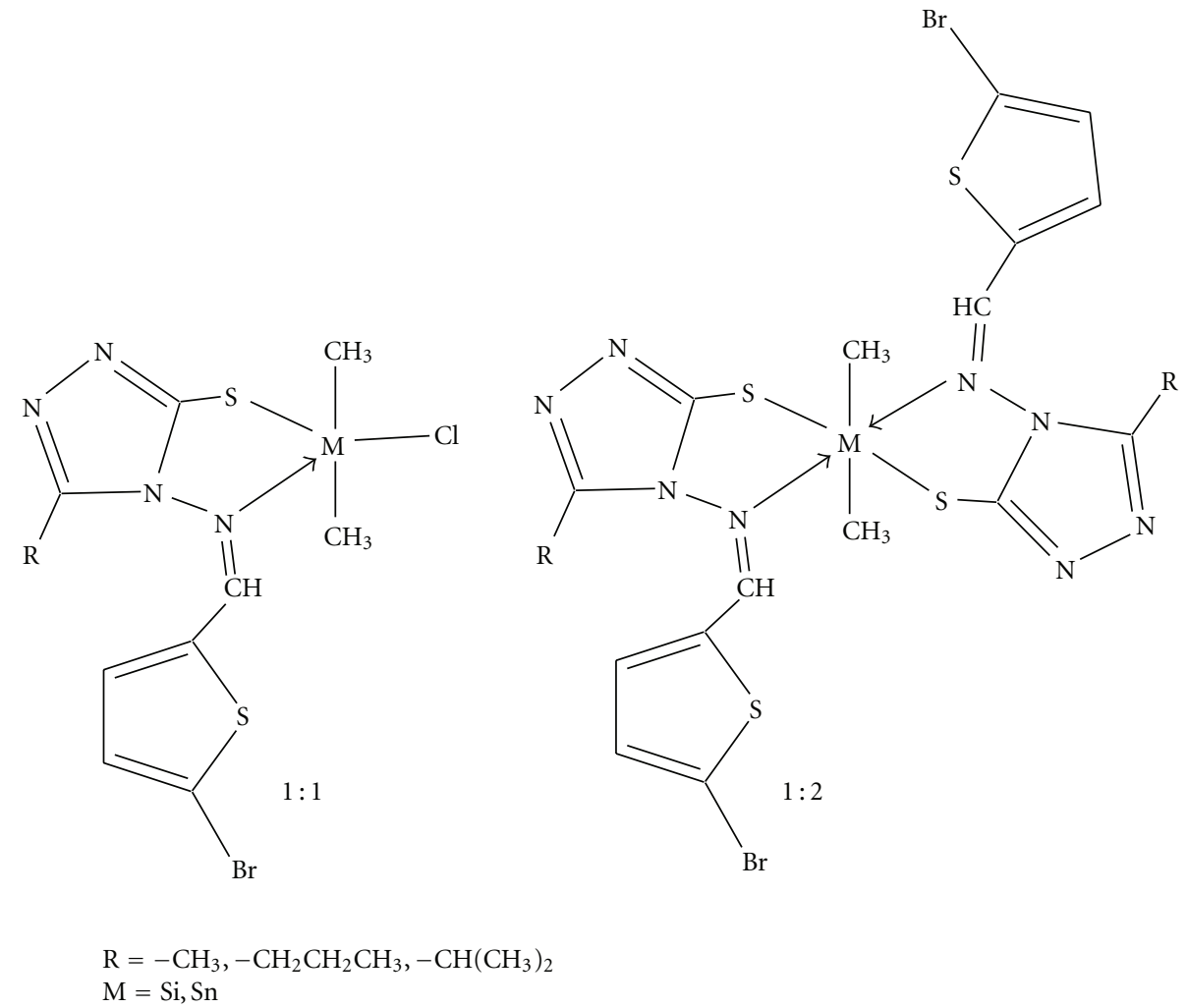

Figure 6: Proposed structures of the $1: 1$ and $1: 2$ complexes, where $1: 1$ complexes, coordination number $=5$ are proposed to have trigonal bipyramidal and $1: 2$ complexes, coordination number $=6$ are proposed to have octahedral geometries.

1 to the tube 10 and excess broth $(100 \mu \mathrm{L})$ was discarded from the test tube no. 10. To each tube, $100 \mu \mathrm{L}$ of standard inoculum $\left(1.5 \times 10^{8} \mathrm{cfu} / \mathrm{mL}\right)$ was added. Ciprofloxacin was used as control. Turbidity was observed after incubating the inoculated tubes at $37^{\circ} \mathrm{C}$ for $24 \mathrm{hrs}$.

4.3. In Vitro Antifungal Activity. The ligands and their metal complexes were also screened for their antifungal activity against two fungi, namely, A. niger and A. flavus, the ear pathogens isolated from the patients of Kurukshetra [34], by poison food technique [35]. The moulds were grown on Sabouraud dextrose agar (SDA) at $25^{\circ} \mathrm{C}$ for 7 days and used as inocula. The $15 \mathrm{~mL}$ of molten SDA $\left(45^{\circ} \mathrm{C}\right)$ was poisoned by the addition of $100 \mu \mathrm{L}$ volume of each compound having concentration of $4.0 \mathrm{mg} / \mathrm{mL}$ reconstituted in the DMSO, poured into a sterile petri plate and allowed it to solidify at room temperature. The solidified poisoned agar plates were inoculated at the center with fungal plugs ( $8 \mathrm{~mm}$ diameter) obtained from the colony margins and incubated at $25^{\circ} \mathrm{C}$ for 7 days. DMSO was used as the negative control whereas Fluconazole was used as the positive control. The experiments were performed in triplicates. Diameter of fungal colonies was measured and expressed as percent mycelial inhibition by applying the formula.

$$
\text { Percent inhibition of mycelial growth }=\frac{d c-d t}{d c \times 100},
$$

where $d c$ is the average diameter of fungal colony in negative control sets and $d t$ is the average diameter fungal colony in experimental sets.
4.4. Observations. The antibacterial data reveals that the complexes are superior compared to the free ligands. The free ligands and their metal complexes are active against Grampositive bacteria (Staphylococcus aureus and Bacillus subtilis) and inactive against gram negative bacteria (Escherichia coli and Pseudomonas aeruginosa). Among the synthesized compounds tested compounds, $\mathrm{Me}_{2} \mathrm{SnCl}\left(\mathrm{L}^{1}\right)$ and $\mathrm{Me}_{2} \mathrm{SiCl}\left(\mathrm{L}^{2}\right)$ show more antibacterial activity that is, near to standard drug (Ciprofloxacin) (Table 5). In the series, the MIC of the compounds ranged between $28-128 \mu \mathrm{g} / \mathrm{mL}$ against Grampositive bacteria. Compound $\mathrm{Me}_{2} \mathrm{SnCl}\left(\mathrm{L}^{1}\right)$ and $\mathrm{Me}_{2} \mathrm{SiCl}\left(\mathrm{L}^{2}\right)$ show highest MIC of $28 \mu \mathrm{g} / \mathrm{mL}$ against $S$. aureus (Table 6). The antifungal activity of compounds (Figure 5 ) shows more than $50 \%$ inhibition of mycelia growth against Aspergillus niger and A. flavus (Table 7). Thus, it can be postulated that further studies of these complexes in this direction could lead to more interesting results.

\section{Conclusion}

Trigonal bipyramidal and octahedral geometries have been proposed for $1: 1$ and 1:2 organosilicon(IV) and organotin(IV) complexes with the help of various physicochemical studies like IR, UV, ${ }^{1} \mathrm{H},{ }^{13} \mathrm{C},{ }^{29} \mathrm{Si}$, and ${ }^{119} \mathrm{Sn}$ NMR (Figure 6). The free ligands, and their metal complexes were screened against various fungi and bacteria to access their potential as antimicrobial agents. The antimicrobial data reveals that the complexes are superior to the free ligands and their toxicity has increased as per the increase in 
concentration. These compounds were found more potent inhibitor of fungal growth as compared to the bacterial culture.

\section{Acknowledgments}

The financial assistance from UGC, New Delhi, vide Major Research Project F. no. 34-317/2008(SR), provided Project fellowship to one of the author (P. Puri), is gratefully acknowledged. The authors are also thankful to the Head, SAIF, CDRI, Lucknow and the Head, SAIF, IIT-Bombay for providing metal NMR and elemental analyses.

\section{References}

[1] M. Pereyre, J. P. Quintard, and A. Rahm, Tin in Organic Synthesis, Butterworth, London, UK, 1987.

[2] D. Marton, U. Russo, D. Stivanello, and G. Tagliavini, "Preparation of benzylstannanes by zinc-mediated coupling of benzyl bromides with organotin derivatives: physicochemical characterization and crystal structures," Organometallics, vol. 15, no. 6, pp. 1645-1650, 1996.

[3] R. C. Mehrotra and A. Singh, Organometallic Chemistry: A Unified Approach, New age international, New Delhi, India, 2000.

[4] L. Pellerito and L. Nagy, "Organotin(IV) ${ }^{n+}$ complexes formed with biologically active ligands: equilibrium and structural studies, and some biological aspects," Coordination Chemistry Reviews, vol. 224, no. 1-2, pp. 111-150, 2002.

[5] K. Shahid, S. Ali, and S. Shahzadi, "The chemistry, properties, and characterization of organotin(IV)complexes of 2-(N-naphthylamido)benzoic acid," Journal of Coordination Chemistry, vol. 62, no. 17, pp. 2919-2926, 2009.

[6] K. C. Joshi, V. N. Pathak, and P. Arya, "Synthesis of some new fluorine containing condensed thiazoles and their fungicidal activity," Agricultural and Biological Chemistry, vol. 41, no. 3, pp. 543-546, 1977.

[7] M. Jain, S. Gaur, S. C. Diwedi, S. C. Joshi, R. V. Singh, and A. Bansal, "Nematicidal, insecticidal, antifertility, antifungal and antibacterial activities of salicylanilide sulphathiazole and its manganese, silicon and tin complexes," Phosphorus, Sulfur and Silicon and the Related Elements, vol. 179, no. 8, pp. 1517-1537, 2004.

[8] K. Singh, Dharampla, and S. S. Dhiman, "Spectral studies and antimicrobial activities of organosilicon(IV) and organotin(IV) complexes of nitrogen and sulfur donor Schiff bases derived from 4-amino-5-mercapto-3-methyl-s-triazole," Main Group Chemistry, vol. 8, no. 1, pp. 47-59, 2009.

[9] T. Sedaghat and Z. Shokohipour, "Synthesis and spectroscopic studies of new organotin(IV) complexes with tridentate Nand O-donor Schiff bases," Journal of Coordination Chemistry, vol. 62, no. 23, pp. 3837-3844, 2009.

[10] K. Singh, P. Puri, and Dharampal, "Synthesis and spectroscopic studies of some new organometallic chelates derived from bidentate ligands," Turkish Journal of Chemistry, vol. 34, no. 4, pp. 499-507, 2010.

[11] C. Saxena and R. V. Singh, "Diorganosilicon(iv) complexes of fluoro-imines: synthetic, spectroscopic and biological aspects," Phosphorus, Sulfur and Silicon and Related Elements, vol. 97, no. 1-4, pp. 17-26, 1994.
[12] U. N. Tripathi, G. Venubabu, M. S. Ahmad, S. S. R. Kolisetty, and A. K. Srivastava, "Synthesis, spectral and antimicrobial studies of diorganotin(IV)3(2'- hydroxyphenyl)-5-(4substituted phenyl) pyrazolinates," Applied Organometallic Chemistry, vol. 20, no. 10, pp. 669-676, 2006.

[13] K. Singh, Dharampal, and V. Parkash, "Synthesis, spectroscopic studies, and in vitro antifungal activity of organosilicon(IV) and organotin(IV) complexes of 4-amino5-mercapto-3-methyl-S- triazole Schiff bases," Phosphorus, Sulfur and Silicon and the Related Elements, vol. 183, no. 11, pp. 2784-2794, 2008.

[14] L. Tiano, D. Fedeli, M. Moretti, and G. Falcioni, "DNA damage induced by organotins on trout-nucleated erythrocytes," Applied Organometallic Chemistry, vol. 15, no. 7, pp. 575-580, 2001.

[15] N. Gerasimchuk, T. Maher, P. Durham, K. V. Domasevitch, J. Wilking, and A. Mokhir, "Tin(IV) cyanoximates: synthesis, characterization, and cytotoxicity," Inorganic Chemistry, vol. 46, no. 18, pp. 7268-7284, 2007.

[16] M. S. Ahmad, M. Hussain, M. Hanif, S. Ali, and B. Mirza, "Synthesis, chemical characterization and biological screening for cytotoxicity and antitumor activity of organotin (IV) derivatives of 3,4-methylenedioxy 6-nitrophenylpropenoic acid," Molecules, vol. 12, no. 10, pp. 2348-2363, 2007.

[17] K. Singh, Dharampal, and S. S. Dhiman, "Synthetic, structural and biological studies of organotin(IV) complexes of schiff bases derived from pyrrol-2-carboxaldehyde," Journal of the Iranian Chemical Society, vol. 7, no. 1, pp. 243-250, 2010.

[18] K. Singh and Dharampal, "Synthetic, structural and biological studies of organosilicon(IV) complexes of Schiff bases derived from pyrrole-2-carboxaldehyde," Journal of the Serbian Chemical Society, vol. 75, no. 7, pp. 917-927, 2010.

[19] S. Bala, R. P. Gupta, M. L. Sachdeva, A. Singh, and H. K. Pujari, "Heterocyclic systems containing bridgehead nitrogen atom: part XXXIII-syntheses of s-Triazolo[I,3,4] thiadiazine, s-Triazolo[3,4,b][I,3,4] thiadiazino[6,7-b]quinoxaline \& as-Triazino [I,3,4]- thiadiazines," Indian Journal of Chemistry, vol. 16, pp. 481-483, 1978.

[20] K. S. Dhaka, J. Mohan, V. K. Chadha, and H. K. Pujari, "Heterocyclic systems containing bridgehead nitrogen atom: part XVI-Syntheses of s-Triazolo[3,4-b][1,3,4] thiadiazines and related heterocycles," Indian Journal of Chemistry, vol. 12, p. 288, 1974.

[21] G. Singh, P. A. Singh, K. Singh, D. P. Singh, R. N. Handa, and S. N. Dubey, "Synthesis and structural studies of some bivalent metal complexes with bidentate Schiff base ligands," Proceedings of National Academy of Sciences India, vol. 72, no. A-2, pp. 87-95, 2002.

[22] P. G. Avaji, S. A. Patil, and P. S. Badami, "Synthesis, spectral, thermal, solid state d.c. electrical conductivity and biological studies of $\mathrm{Co}(\mathrm{II}), \mathrm{Ni}(\mathrm{II})$ and $\mathrm{Cu}(\mathrm{II})$ complexes with 3substituted-4-amino (indole-3-aldehydo)-5-mercapto-1,2,4triazole Schiff bases," Journal of Coordination Chemistry, vol. 61, no. 12, pp. 1884-1896, 2008.

[23] B. K. Sinha, R. Singh, and J. P. Srivastava, "Substituted 1,2,4-triazoles as complexing ligands-I Ni(II), Co(II), $\mathrm{Cu}(\mathrm{II}), \mathrm{Zn}(\mathrm{II}), \mathrm{Pd}(\mathrm{II}), \mathrm{Cd}(\mathrm{II})$ and $\mathrm{Pb}(\mathrm{II})$ complexes with 4-amino-3,5-dimercapto-1,2,4-triazole," Journal of Inorganic and Nuclear Chemistry, vol. 39, no. 10, pp. 1797-1801, 1977.

[24] K. Singh, R. V. Singh, and J. P. Tandon, "Synthesis and structural features of organo Si(IV) imine complexes," Polyhedron, vol. 7, no. 2, pp. 151-154, 1988.

[25] S. Belwal and R. V. Singh, "Bioactive versatile azomethine complexes of organotin(IV) and organosilicon(IV)," Applied Organometallic Chemistry, vol. 12, no. 1, pp. 39-46, 1998. 
[26] K. Singh, D. P. Singh, M. S. Barwa, P. Tyagi, and Y. Mirza, "Antibacterial $\mathrm{Co}(\mathrm{II}), \mathrm{Ni}(\mathrm{II}), \mathrm{Cu}(\mathrm{II})$ and $\mathrm{Zn}(\mathrm{II})$ complexes of Schiff bases derived from fluorobenzaldehyde and triazoles," Journal of Enzyme Inhibition and Medicinal Chemistry, vol. 21, no. 5, pp. 557-562, 2006.

[27] Suresh, P. Srinivas, T. Suresh, M. Revanasiddappa, and S. Khasim, "Synthetic, spectral and thermal studies of tin(IV) complexes of 1, 5-benzodiazepines," E-Journal of Chemistry, vol. 5, no. 3, pp. 627-633, 2008.

[28] M. Nath, S. Goyal, and S. Goyal, "Synthesis, spectral and biological studies of organosilicon(IV) complexes of Schiff bases derived from amino acids," Synthesis and Reactivity in Inorganic and Metal-Organic Chemistry, vol. 30, no. 9, pp. 1794-1804, 2000.

[29] A. Chaudhary and R. V. Singh, "Studies on biologically potent tetraazamacrocyclic complexes of bivalent tin," Phosphorus, Sulfur and Silicon and the Related Elements, vol. 178, no. 3, pp. 615-626, 2003.

[30] M. Pellei, G. G. Lobbia, M. Ricciutelli, and C. Santini, "Synthesis and spectroscopic characterization of new organotin(IV) complexes with bis(3,5-dimethylpyrazol-1-yl)dithioacetate," Journal of Coordination Chemistry, vol. 58, no. 5, pp. 409-420, 2005.

[31] I. Ahmad and A. Z. Beg, "Antimicrobial and phytochemical studies on 45 Indian medicinal plants against multi-drug resistant human pathogens," Journal of Ethnopharmacology, vol. 74, no. 2, pp. 113-123, 2001.

[32] J. M. Andrews, "Determination of minimum inhibitory concentrations," Journal of Antimicrobial Chemotherapy, vol. 48, no. 1, pp. 5-16, 2001.

[33] NCCLS, Method for Dilution Antimicrobial Susceptibility Test for Bacteria That Grow Aerobically, Approved Standards, National Committee for Clinical Standards, Villanova, Pa, USA, 5th edition, 2000.

[34] K. R. Aneja, C. Sharma, and R. Joshi, "Fungal infection of the ear: a common problem in the north eastern part of Haryana," International Journal of Otorhinolaryngology, vol. 74, no. 6, pp. 604-607, 2010.

[35] S. K. S. Al-Burtamani, M. O. Fatope, R. G. Marwah, A. K. Onifade, and S. H. Al-Saidi, "Chemical composition, antibacterial and antifungal activities of the essential oil of Haplophyllum tuberculatum from Oman," Journal of Ethnopharmacology, vol. 96, no. 1-2, pp. 107-112, 2005. 


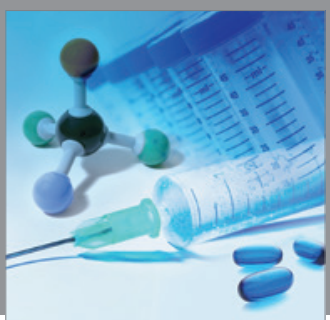

International Journal of

Medicinal Chemistry

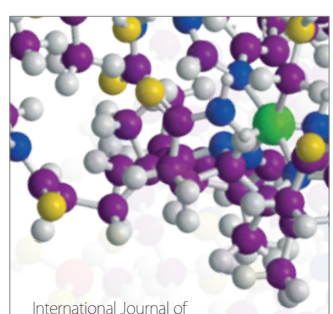

Carbohydrate Chemistry

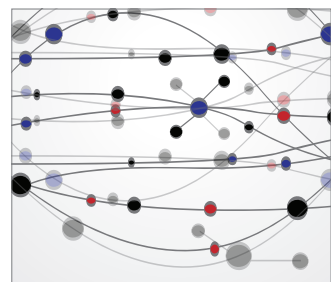

The Scientific World Journal
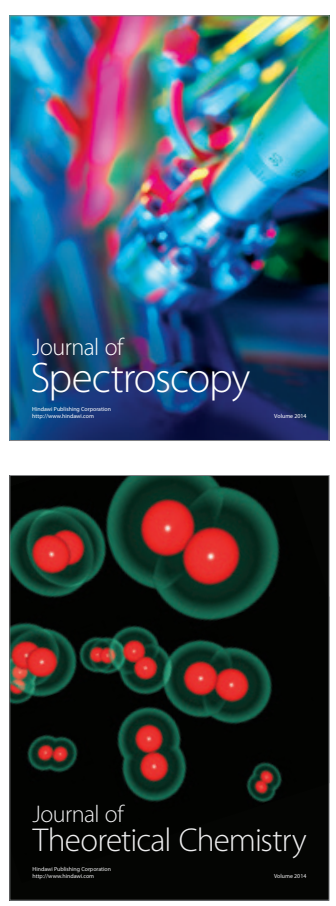
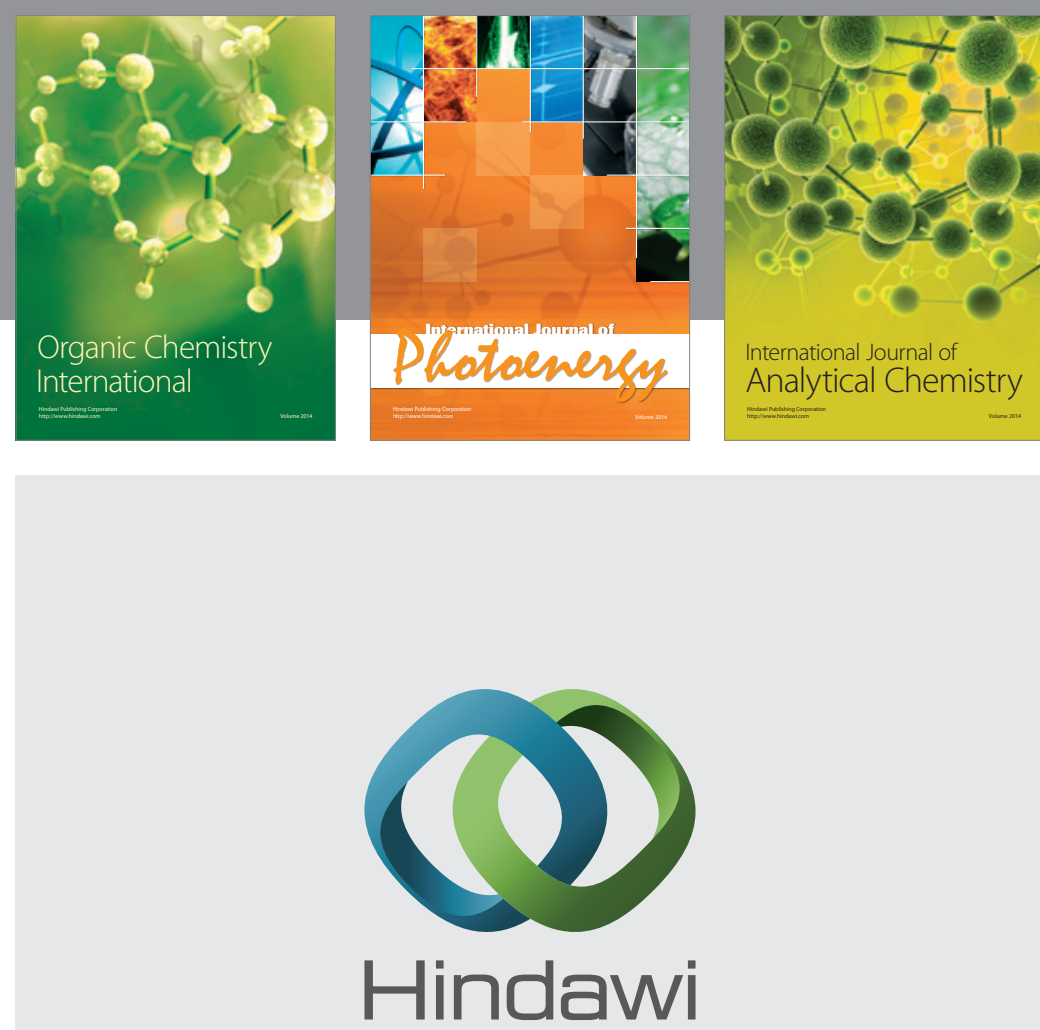

Submit your manuscripts at

http://www.hindawi.com
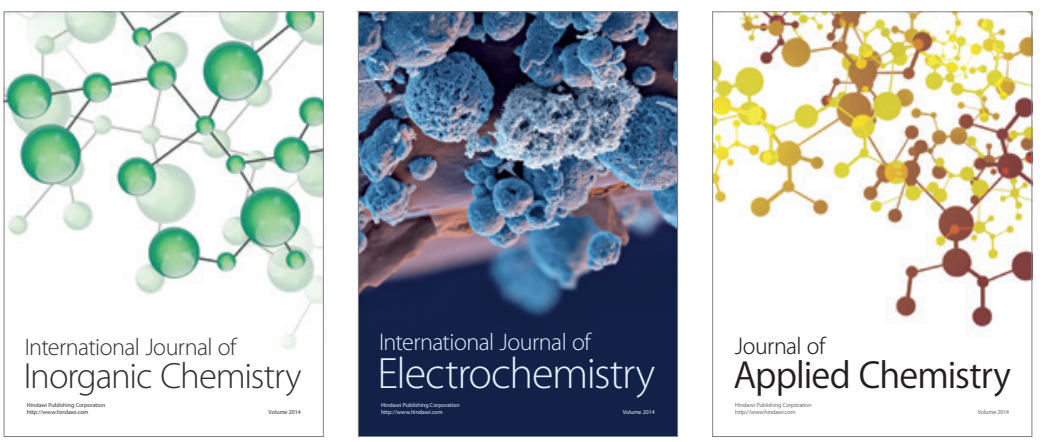

Journal of

Applied Chemistry
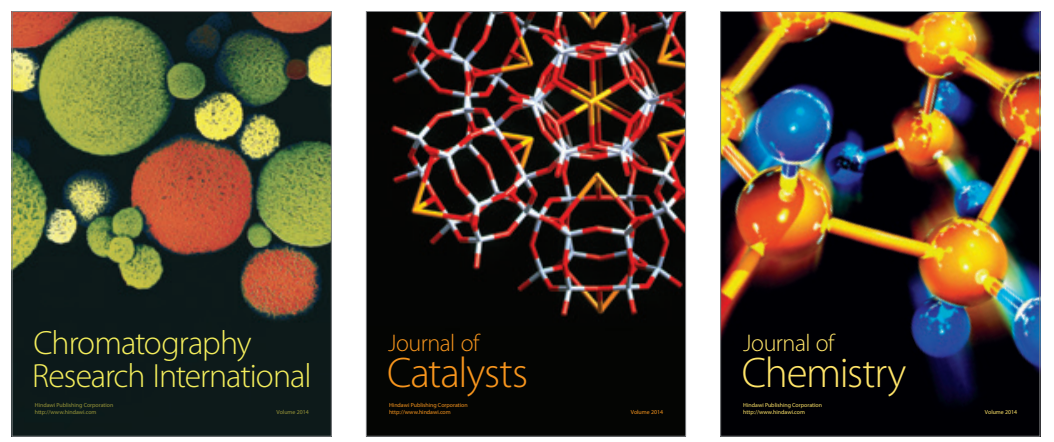
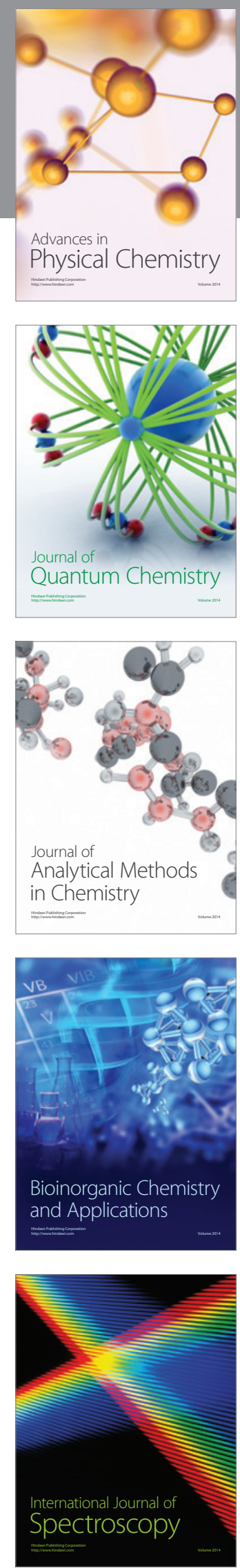